\title{
Flipped Materials of Wetland Texts for English Teaching at Faculty of Teacher Training and Education, Lambung Mangkurat University
}

\author{
Elvina Arapah, Dini Noor Arini \\ Universitas Lambung Mangkurat \\ elvina_arapah@ulm.ac.id
}

\begin{abstract}
Although smartphones were not prohibited in the campus environment in Era 4.0, smartphones were still limited in their use as a means of communication and connection. Supposedly, the use of this smartphone must of course be observed wisely and maximized by various related parties, for example by making it a medium for learning. The challenge faced in maximizing the use of smartphones for learning is the limitations in processing and or managing existing material. With the various backgrounds and reasons outlined above, the study tries to develop Flipped Materials for English Courses at the Faculty of Teacher Training and Education, Lambung Mangkurat University. This research uses research and development type for Flipped Material on Wetlands in digital form which is developed and tested for its feasibility in a limited scope. For this research, the study took samples with consideration of feasibility in reaching the subjects. Sampling is done by using the Cluster Random Technique because the characteristics of the population used as the research subject are considered to be the same, namely students of ULM semester $I$.
\end{abstract}

Keywords: literasi_digital, flipped_material, wetlands

\section{INTRODUCTION}

\subsection{Background}

The use of devices in the form of smart phones has been so prevalent in various circles. One of them is among college students. Even though the use of smartphones was not prohibited in the campus environment in the era of 4.0, smartphones are still limited in their use as a means of communication and connection. various related parties, for example by making it a medium in learning. It is important to see how the use of smartphones as learning media outside the network (offline) and online. 
The challenge faced in maximizing the use of smartphones for learning is the limitations in processing and /or managing existing material to be more focused on increasing digital literacy. The making of electronic materials such as electronic books really requires experts in the field of information technology. The management of electronic materials itself also requires technology literate personnel. As a resource for smartphone users, Lecturers seem to be unable to fully utilize the offline and online modes available to assist learning in their classes.

Therefore, for lecturers, smartphones' widespread use can be used to train and improve students' digital literacy, especially for electronic materials in English. Various studies have found that students' level of speed and reading ability in English is still lacking. This should trigger teachers to try various ways, one of which is the use of smartphones both offline and online. With the various backgrounds and reasons outlined above, the proposer tries to find student digital literacy for Wetlands and develops Flipped Materials for English Courses at the Faculty of Teacher Training and Education, Lambung Mangkurat University. The research problem under study is formulated in the form of the following questions: How is the development of Flipped Materials in learning English for Wetlands in English Courses at the Faculty of Teacher Training and Education, Lambung Mangkurat University? 


\section{THEORETICAL SUPPORT}

\section{Offline and Online}

According to Ardi (https://bfl-definisi.blogspot.co.id/2016/12/arti-dari-kata-daringdan-luring.html; accessed April 5, 2018), online often stands for "in the network ", where the word online is to replace the word" online "which we often use in connection with internet technology. So when we hear the phrase" online learning ", it means learning that is done online is like using edmodo.Edmodo itself is a web that provides social networkinglike learning platform that we can use for free. Here all material is distributed online, communication is also carried out online (such as Facebook chat facilities) and examinations are also online. One example of a site that must be accessed online is the following site www.w3schools.com/css/css_syntax.asp.Luring this is an acronym for "outside the network", where the word offline is to replace the word "offline". The word "offline" is the opposite of "online". Because the word "offline" is to replace the English word "offline", the meaning of the word "offline" is in no way connected to the internet or intranet. Because there are still some people classify "online" as internet connected online and "offline" as an intranet. One of the url addresses which means it is accessed offline is file: /// D: / E-Book / w3schools_offline, which starts with the word file followed by the name of the drive and folder.

\section{Flipped Material}

According to Kurnia and Astuti (2017: 150), Internet users in Indonesia have reached $51.8 \%$ of the total population of Indonesia. The composition can be said to be balanced between men $(52.5 \%)$ and women $(47.5 \%)$. This allows for a mixed learning process (blended learning) which seems to be more effective for learners in this millennial era. 
Catle (2018: 3-4) in his study recounts the conditions that occur in the Philippines, where as a result of a shortage of teachers, classes, facilities and equipment, the learning period in class is shortened per subject with narrow class room sizes. This of course reduces the quality of the learning carried out. For this reason, then Catle (2018: 4) developed Flipped Instructional Material online for certain topics in Chemistry lessons that can be used by local teachers in their area according to the curriculum for the K-12 Program.

Flipped Materials offered various conveniences or benefits. Catle (2018: 12) quotes from Brame (2013), the Vanderbilt University Teaching Center identifies important elements in the use of Flipped Materials. First, this strategy provides an opportunity for students to get the first exposure to content before class. Second, Flipped Material that is given earlier can provide incentives for students to prepare themselves for learning. Third, Flipped Material conditions activities in the classroom that focus on higher levels of cognitive activity. Finally, an important element that will be explored is the opening of a broad mechanism for assessing student understanding because class meeting time is used more for critical thinking, not knowledge acquisition.

These four elements are supported by the research results of Lepp and Tonisson (2015: 225) which conclude that:

"Two thirds of the students think that the flipped classroom approach helps them to learn better and more than they would learn in traditional class."

In their research, students as respondents were asked for their opinions after attending a classroom learning workshop using the Flipped Classroom Approach. Two thirds of respondents admit that this approach helps them learn better. Lepp and Tonisson's 
research was conducted in the field of computer programming. Research has not been found that implemented Flipped Material in the field of teaching English, especially for learning reading skills.

Teachers can combine face-to-face interactions with online learning to increase digital literacy. According to Basyah (2018: 3) Flipped Classroom Material is material in instructional videos, Teaching Material Books, and Practice Guidelines distributed in the form of files and owned by each student. Furthermore, according to him, the Flipped Classroom principle is a learning method in which the theory class is no longer in school but is reversed anywhere.Shing Mei \& Keng Wah (2015) compare the Traditional Class and the Flipped Classroom as shown in Table 2.

Table 2. Comparison between Traditional Class and Flipped Classroom

\begin{tabular}{|l|l|l|}
\hline \multicolumn{1}{|c|}{ Learning } & \multicolumn{1}{|c|}{ Traditional classroom } & \multicolumn{1}{c|}{ Flipped Classroom } \\
\hline In class & Teacher instructs/ lectures in & Students complete assessments \\
& class while students take notes. & and homework while getting \\
\hline Class & Students complete assessments & Teacher instructs lesson \\
& and homework given by teacher. & through video, books, websites, \\
& & etc. while students learn from \\
& & the sources. \\
\hline
\end{tabular}


According to Shing Mei \& Keng Wah, learning that occurs both in the classroom for these two types of learning lies in what teachers and students do. In traditional classrooms, teachers provide more lectures and students take notes. In the Flipped Classroom, students are more active in solving problems guided by the teacher. Meanwhile, outside the classroom, students are given various assignments and homework in the Traditional Class. Meanwhile, in the Flipped Classroom, the material is given through various media as a learning resource.

The advantages of Flipped Classroom or Flipped Learning have of course been proven through research from various scientific fields. Research from Gillispie (2016: 35) shows that there has been an increase in learning outcomes in students in the Department of Obstetrics and Gynecology at the University of Queensland, Los Angeles, after the implementation of learning with Flipped Classroom. Lee and Park's research (2018: 76) also found that the Flipped Learning group improved their ability to set goals, selfleadership beliefs, and capacity for rational problem solving more than the Traditional Learning group. There is a wealth of evidence demonstrating that an active e-learning approach improves cognitive abilities, including critical thinking.

\section{Development Model}

Dick, Carey, and Carey conceptualise learning design as a system and learning as a systematic process. Indeed, this methodical approach is embodied in the systems approach model. Dick, Carey, and Carey emphasise that the systems approach always refers to the general stages of instructional systems development (Instructional Systems Development / ISD). When discussing design issues, incorporate them into the process; the term Instructional Design (ID) refers to Instructional System Development (ISD), specifically 
the stages of analysis, design, development, implementation, and evaluation. The umbrella field is instructional design.

The learning system design model proposed by Dick and Carey has long been used to create effective, efficient and attractive learning programs. The model developed is based on the use of a systems approach or system approach to the basic components of a learning system design which includes analysis, design, development, implementation, and evaluation. This model consists of several components and sub-components that need to be done to design a larger activity. The development of this learning system design model is obtained from theory and research results and practical experience gained in the field. The implementation of this learning system design model requires a systematic and comprehensive process. This is necessary to be able to create a learning system design that can be used optimally in overcoming learning problems. The steps of the Dick and Carey model can be explained as follows:

1. Identification of needs and determining general goals, this is the initial stage, namely determining what needs are desired so that students can do it when they have completed the learning program and determine the general goals to be achieved.

2. Conducting an instructional analysis, namely determining what abilities are involved in the learning process to achieve goals and analyzing the topics or material to be studied.

3. Identifying the initial behavior and characteristics of students, when analyzing the skills that need to be trained or learned and the stages of procedures that need to be passed, the students' initial skills are also considered. 
4. Formulate performance goals or specific learning objectives. Based on instructional analysis and statements about students' initial behavior, a specific statement is formulated about what students should do after completing the lesson.

5. Development of benchmark reference tests. The development of a benchmark reference test is based on formulated objectives.

6. Development of learning strategies. Information from the previous five stages, a learning strategy is developed to achieve the final goal.

7. Development or selecting learning materials. This stage will be used to select or develop learning materials including instructional instructions for students, materials, tests and teacher guides.

8. Design and carry out formative evaluations. Formative evaluation is carried out to collect data, identify data, process data, and analyze data about the program being developed. The results are to describe whether the program developed is good or not. If not, it must be revised and if it has, it must be maintained.

9. Design and carry out summative evaluations. This stage is an advanced stage to see the usefulness of the program after being implemented in the field.

10. Revision of learning. This stage repeats the learning system development cycle. Data from summative evaluations that have been carried out in the previous stage are analyzed and interpreted.

The characteristics of the main R \& D steps used are Borg and Gall (2003), namely: 
a. Conducting initial studies or research to find research findings related to the product to be developed.

b. Develop a product based on the research findings.

c. Conduct field tests in actual settings or situations in which the product will be used.

d. Make revisions to fix weaknesses found in the field test stages.

\section{METHOD}

This research uses a type of research and development study, namely the development of Flipped Material for Wetlands in digital form, developed and tested for its feasibility in a limited scope. The population of this study were all study programs in the Teaching and Education Faculty (FKIP), Lambung Mangkurat University (ULM). At the Faculty of Teacher Training and Education (FKIP), Lambung Mangkurat University (ULM), there are 21 study programs which in the Academic Year 2020/2021 require English I in the first semester in the Independent Learning-Campus Free Curriculum (MBKM) Sample selected randomly with considerations of feasibility in research through the Cluster Random Technique because the characteristics of the study population are considered the same, namely the first semester ULM students. English I in Academic year 2020/2021. The development model used is an adaptation of Dick and Carey (2001) and Borg and Gall (2003). For the development of Flipped Material for Wetlands, the instruments used are made according to the development stages. 


\section{RESULT AND DISCUSSION}

The results of the research implementation that have been achieved include development steps and the feasibility of Flipped Material in learning English for Wetlands material. Three of these four things have been implemented and included in the progress report of this research so that only three research focuses are included in this report.

The procedure for developing flipped material teaching materials in this study uses a research procedure whose steps are carried out in the Covid 19 Pandemic so that there are limitations that must be tolerated. By adapting the main development research steps from Dick and Carey (2001) and Borg and Gall (2003), the development step is simplified into four main steps.

1. Initial study or research to find research findings related to the product to be developed

The form of study or initial research is the identification of problems in the use of learning materials in class through a review of existing teaching materials, namely the IRDH published textbook in 2017 entitled English for University Students where the designation is English Language Courses. Next is the analysis of the syllabus or semester learning plan (RPS), especially analyzing the CPL, CPMK and KATP.

\section{Product development based on initial research findings.}

The drafting of Flipped Matrial teaching materials is based on the needs of students, both as stated in the syllabus or RPS or according to the ongoing situation and conditions. Flipped Material can be the answer where learning conditions during the Covid 19 
Pandemic are more directed online. Still more or less the same as the predecessor material in book form, this Flipped Material also emphasizes Reading Comprehension material because the need for reading is prioritized in higher education.

Expert validation was carried out in a limited manner to determine the suitability of the draft Flipped Material teaching materials with the RPS. After this content validation has been done, revision is the next step. Revising the draft Flipped Material teaching materials must be based on the results of expert validation.

\section{Field tests in actual settings or situations where the product will be used.}

The trial of Flipped Material teaching materials in English courses was carried out twice, namely in small groups of student representatives from several study programs. At the beginning of the 2020/2021 academic year, all ULM students took the Cambridge English Placement Test (CEPT), including FKIP students. Of the four study programs that were the research samples, 2 students with the lowest and highest levels of CEFR Level were directly proportional to the results of the trial scores. In other words, the Flipped Material used is in accordance with the English skills of the students who are the limited trial sample. On a larger scale, Flipped Material. Flipped Material was tried out on a larger scale on students from the Classroom Mathematics and Biology Education Study Program.

In the group scale trial, it was also seen that the results of the CEPT which were stated in the CEFR level showed results that were directly proportional to the scores of students for the Flipped Material trial. At this stage, it can be concluded that the Flipped Material being developed can be accepted according to the students' abilities. 


\section{Revisions to correct weaknesses found in the field test stages.}

Revising Flipped Material teaching materials based on limited-scale and group trials was carried out by looking at student achievement, especially by analyzing the lowest and highest number of scores. If there are too many low scores, then the Flipped Material calculation is still too difficult and must be revised. Likewise, it is seen that students achieved more high scores. This means that the questions are still too easy for the student level so that the Flipped Material developed needs to be revised in terms of reading, both text length and vocabulary difficulty, and in terms of questions, it is by reviewing the types and levels of difficulty of the questions.

\section{CONCLUSION}

In this study, a problem formulation is the focus, namely about the development of Flipped Materials, focusing on the steps to develop Flipped Materials in learning English for Wetlands and the feasibility of Flipped Materials in learning English for Wetlands. Thus, it can also be concluded that the Flipped Material that was developed up to the group trial stage still needs to be revised to suit the students' abilities, which can meet the needs of students in English lectures.

Suggestions for research plans in the following year based on the output indicators that have been achieved are a set of flipped materials that have been successfully recorded in the form of digital material that can be accessed offline because in this study all material is presented online. For future research on the implementation of Flipped Material, it is hoped that it will be more comprehensive in material units for a course, not limited to 
English Education: Jurnal Tadris Bahasa Inggris

pISSN 2086-6003 | eISSN 2580-1449

Vol. 14 (1), 2021, 47-61

English courses for study programs outside English Education, because this research only produces samples of Flipped Materials.

\section{ACKNOWLEDGMENT (OPTIONAL)}

Gratitude conveyed to the Institute for Research and Community Service, University of Lambung Mangkurat, who funded this research in the 2020 Compulsory Research Lecturer Program. 


\section{REFERENCES}

Ardi, Malvin. (2016). Arti dari Kata Daring dan Luring serta perbedaannya.https://bfldefinisi.blogspot.co.id/2016/12/arti-dari-kata-daring-dan-luring.html diakses pada 5 April 2018

Basyah, A. (2018:3) Flipped Classroom Material untuk Meningkatkan Minat $\begin{array}{llll}\text { Technopreneur } & \text { Siswa } & \text { SMK } & \text { diakses }\end{array}$ https://www.researchgate.net/publication/327698349

Borg, W.R and Gall, M.D. (2003). Educational Research: An Introduction 4 th Edition. London: Longman Inc.

Catle (2018) A Flipped Instructional Material in Science diakses dari https://www.researchgate.net/publication/327989101 pada DOI: 10.13140/RG.2.2.14247.60327

Dick and Carey. (2001). The Systematic Design of Instruction. New York: Longman.

Dick, W., Carey, L., \& Carey, J. O. (2001). The systematic design of instruction. New York:

Dick, W., Carey, L., \& Carey, J. O. (2001). The systematic design of instruction. New York:

Gillispie, V. (2016). Using the Flipped Classroom to Bridge the Gap to Generation Y Ochsner. Journal 16:32-36, 2016

Lee dan Park (2018). Effects of Flipped Learning Using Online Materials in a Surgical Nursing Practicum: A Pilot Stratifed Group-Randomized Trial dalam The Korean Society of Medical Informatics. January;24(1):69-78 
Lepp, M. \& Tonisson, E. (2015) Integrating Flipped Classroom Approach and Work in Pairs into Workshops in Programming Course diakses dari https://www.researchgate.net/publication/28200219

Shing Mei \& Keng Wah (2015). Flipping the Classroom: A Module Redesign to Foster Active Learning in Materials Science diakses dari https://www.researchgate.net/publication/280940298

Walter Dick, Lou Carey. 2001. The Systemic Design of Instruction. United State: AddisonWesley Educational Publishers Inc 